\title{
SPRITUALITAS DALAM PENDIDIKAN ISLAM
}

\author{
Oleh: Mulyadi Hermanto Nst
}

\begin{abstract}
Spiritual-based education must be able to touch the innermost side of the learner or heart, so that learners know and realize that he was created by God, born into the world with the duty of worship, able to live grateful, loving fellow human beings and other creatures because Allah alone, diligent worship, caring for others, respect for parents and teachers. If spiritual values are embedded in the subconscious of the learners, their lives will always be colored with positive, proactive, productive, progressive, participative, and last but not least, humble attitude, tawadhu and taqwa attitudes.

When we talk about Islamic education, we must look at both the formal and the non-formal with the understanding and have the principle of integration, balance, equality, lifelong education and the principle of priority to anticipate the misbehavior that can hinder the goal.
\end{abstract}

\section{Keywords: Sprituality, Principles and Characteristics of Islamic Education.}

\section{A. Pendahuluan}

Kita semua patut prihatin, dengan mencermati kehidupan saat ini, dengan tingkat kriminalitas yang semakin meningkat baik kualitas maupun kuantitas, gaya hidup konsumenisme dan hedonisme, sikap hidup ingin serba instan, meterialisme, dan lain-lain. Jika kecenderungan kehidupan seperti tersebut dibiarkan maka tidak mustahil cepat-lambat bangsa ini akan jauh tertinggal bahkan jatuh ke jurang kehancuran.

Kehidupan kita saat ini adalah cerminan dari kondisi sebelumnya atau masa lalu. Dan kehidupan saat ini akan mewarnai kondisi kehidupan di masa depan. Pendidikan dan pembudayaan merupakan hal yang sangat penting dalam proses pemaknaan dan pewarnaan kehidupan manusia, baik pribadi maupun kelompok.Keadaan kehidupan kita saat ini merupakan cerminan dari preoses pendidikan yang dijalankan sebelumnya.Kita bisa melihat bagaimana bangsabangsa yang maju pada saat ini, mereka telah menginvestasikan pendidikan yang 
bermutu sebelumnya. Penyelenggaaan pendidikan tidak bisa main-main, sambilan atau setengah hati, karena pendidikan seorang atau suatu bangsa akan sangat berperan bagi kemajuan kehidupan di masa yang akan datang.

Saat ini kita masih belum puas dengan sistem dan model pendidikan yang tengah berjalan, yang dinilai masih parsial, apa adanya, belum maksimal, belum mampu menjawab tantangan jaman dan belum mampu membentuk esensi pendidikan, yaitu membangun dan membentuk peserta didik yang berkarakter unggul serta menjunjung tinggi nilai-nilai moral dan spriritual.

Pendidikan kita saat ini hanya sibuk dengan pengembangan otak sebelah kiri, parsial, dan hanya melahirkan pribadi yang terpecah (split personality). Sejatinya penedidikan harus mampu membangun sumber daya insani yang utuh (holistik), terpadu (integrated), mampu mengembangkan dengan seimbang seluruh potensi yang dimiilikinya antara potensi akal, emosi, badan, dan ruhani. Hasil pendidikan menunjukkan dari sekian potensi yang ada, potensi spiritual merupakan dasar dan inti kehidupan manusia.Seorang filosof bernama Tierde Cardin menyebutkan bahwa manusia bukanlah makhluk dunia yang mengalami kehidupan akhirat (spiritual).Namun manusia adalah makhluk spiritual yang mengalami kehidupan dunia.Ungkapan ini mengandung makna yang sangat dalam dan menarik untuk dicermati, bahwa dimensi spiritual pada manusia sangatlah urgen untuk diperhatikan.

\section{Pendidikan berbasis spiritual}

Kehidupan di dunia ini bukanlah tujuan tetapi hanyalah prose (sementara), dan akan terus maju menuju alam keabadian alam akhirat. Konsep dan gagasan seperti itu penting untuk dipahamkan kepada siswa sehingga mampu memahami dan memaknai kehidupan dengan benar. Untuk itu , teori dan praksis pendidikan yang saat ini dijalankan harus berbasis dan berorientasi nilai-nilai spiritual. Dengan tidak menafikan perjuangan kehidupan di dunia ini, pendidikan berbasis spiritual merupakan ruh atau jiwanya dari keseluruhan proses pendidikan dan kehidupan siswa. 
Pendidikan berbasis spiritual harus mampu menyentuh sisi paling dalam peserta didik yaitu hati atau kalbunya, sehingga peserta didik tahu dan sadar bahwa dirinya diciptakan Allah, lahir ke dunia dengan tugas ibadah, mampu hidup bersyukur, menyayangi sesama manusia dan makhluk lainnya karena Allah semata, taat dan rajin beribadah, peduli pada sesama, hormat pada orangtua maupun guru. Jika nilai-nilai spiritual tertanam di dalam lubuk sanubari para siswa, niscaya kehidupan anak akan senantiasa diwarnai dengan sikap positif, proaktif, produktif, progressif, partisipatif ,dan last but not least, memiliki sikap rendah hati, tawadhu serta taqwa .

\section{Tahapan pendidikan spiritual}

Untuk membangun model pendidikan dan pembelajaran berbasis spiritual, tahap-tahap yang harus diikutinya meliputi; Pertama, adalah pemaknaan pada tahap ini peserta didik sesuai dengan tingkat perkembangan usianya, harus mengetahui dan memahami tentang makna (arti) belajar dan pendidikan, mengapa belajar itu penting, untuk apa dan karena siapa?. Pada tahap ini peran nilai-nilai karena tujuan pendidikan harus sejalan dan sejalin dengan tujuan hidup umat manusia. Anak harus paham bahwa sekolah atau pendidikan harus dimaknai dan diniat ibadah kepada Sang Maha pencipta, Allah Swt. Kedua, membangun dan menanamkan motivasi yang kuat yang bersumber dari nilai-nilai spiritual tadi. Bahwa niatnya ibadah, tujuannya ridha Allah orientasinya pahala akhirat.Ketiga, membangun sikap positif.Sikap dalam belajar dan hidup merupakan hal yang sangat penting. Sikap positif, optimisme, penuh syukur, sabar, tawakal niscaya akan membentuk pribadi atau karakter yang unggul, pantang menyerah. Keempat, menembangkan kemampuan (skill), keterampilan dan hidup, baik yang bersifat umum atau khusus sangatlah penting. Setiap anak harus mampu memahami segala fenomena kehidupan dengan kecakapan yang dimilikinya, kecakapan berfikir, komunikasi, menggali informasi, hidup bersama dengan yang lain dan sebagainya. Kelima, membangun wawasan/ pengetahuan. Dengan semakin bertambah usia, bertambah pula wawasan dan pengetahuannya, sehingga semakin dalam pula penganalan dan kecintaannya terhadap Sang Pencipta. Melalui pengetahuan yang 
terus berkembang diharapkan anak semakin paham dan sadar tentang fenomena kehidupan.Keenam, pembiasaan, pembudayaan atau latihan. Manusia adalah apa yang sering dilakukannya secara berulang-ulang. Pembiasaan atau pembudayaan sangatlah penting bagi manusia atau belajar.Hal-hal yang benar, baik, dan bagus harus dibiasakan dan dibudayakan sehingga lambat laun menjadi kepribadian atau karakter.Dalam agama yang namanya peribadahan dilaksanakan berulang-ulang dibiasakan.Menurut Stephen R. Covey dalam bukunya "Tujuh Kebiasaan Manusia yang Sangat Efektif", manusia dapat meraih keberhasilan dalam hidup dengan memiliki dan terus mengembangkan kebiasaan-kebiasaan yang efektif atau bagus.Ketujuh, prestasi atau performa. Hasil positif akan mendorong motivasi dan prestasi baru. Untuk meraih prestasi optimal peserta didik harus berawal dari pemaknaan yang benar.

\section{Hasil pendidikan spiritual}

Terdapat minimal 10 hal yang secara integratif dan berkesinambungan harus didapatkan siswa selama mereka belajar atau mengenyam pendidikan di sekolah. 1) Pahala, 2)Pengampunan, 3)Pengalaman positif dan konstruktif, 4) Penghargaan, 5) Persahabatan yang semakin akrab, 6) Pengetahuan yang luas, 7) Pendidikan (sikap), 8) Pemahaman baru (insight), 9) Prestasi terbaik, 10) Penghasilan. Kesepuluh hal tersebut nyata dan riil harus didapatkan peserta didik dalam jenjang dan tingkat pendidikan apapun, dan semuanya merupakan integrasi dari dimensi duniawiyah dengan ukhrawiyah. Para siswa harus paham dan yakin bahwa mereka akhirnya akan memperoleh dua rapor, yaitu rapor atau nilai di dunia ini dan rapor atau nilai di akhirat nanti. Keduanya mutlak harus dipahami diperjuangkan dan tentu saja diraih.

\section{B. Prinsip Pendidikan Islam}

Pendidikan Islam merupakan pengembangan pikiran, penataan perilaku, pengaturan emosional, hubungan peranan manusia dengan dunia ini, serta bagaimana manusia mampu memanfaatkan dunia sehingga mampu meraih tujuan kehidupan sekaligus mengupayakan perwujudannya.Seluruh ide tersebut telah 
tergambar secara utuh dalam dalam suatu konsep dasar yang kokoh.Islam pun telah menawarkan konsep akidah yang wajib diimani agar dalam diri manusia tertanam perasaan yang mendorongnya pada perilaku normatif yang mengacu pada syariat Islam.Perilaku yang dimaksud adalah penghambaan manusia berdasarkan pemahaman atas tujuan penciptaan manusia itu.

Ketika kita membicarakan pendidikan islam, maka kita harus memandang secara menyeluruh baik yang bersifat formal maupun non formal seperti pesatren, organisasi dan lain-lain. Tapi sebelum itu kita harus mengetahui prinsip-prinsip yang perlu diketahui, karena tujuan dari prinsip sendiri, untuk mengantisipasi pada penyelewengan-penyelewengan yang bisa menghambat dari pada tujuan.

Memang tidak diragukan bahwa ide mengenai prinsip-prinsip dasar pendidikan Islam banyak tertuang dalam ayat-ayat al Qur'an dan hadits nabi. Dalam hal ini akan dikemukakan ayat-ayat atau hadits-hadits yang dapat mewakili dan mengandung ide tentang prinsip prinsip dasar tersebut, dengan asumsi dasar, seperti dikatakan an-Nahlawi bahwa pendidikan sejati atau maha pendidikan itu adalah Allah yang telah menciptakan fitrah manusia dengan segala potensi dan kelebihan serta menetapkan hukum-hukum pertumbuhan, perkembangan, dan interaksinya, sekaligus jalan yang harus ditempuh untuk mencapai tujuannya. Prinsip prinsip tersebut adalah sebagai berikut:

Pertama, Prinsip Integrasi. Suatu prinsip yang seharusnya dianut adalah bahwa dunia ini merupakan jembatan menuju kampung akhirat. Karena itu, mempersiapkan diri secara utuh merupakan hal yang tidak dapat dielakkan agar masa kehidupan di dunia ini benar-benar bermanfaat untuk bekal yang akan dibawa ke akhirat. Perilaku yang terdidik dan nikmat Tuhan apapun yang didapat dalam kehidupan harus diabdikan untuk mencapai kelayakan-kelayakan itu terutama dengan mematuhi keinginan Tuhan. Allah Swt Berfirman,

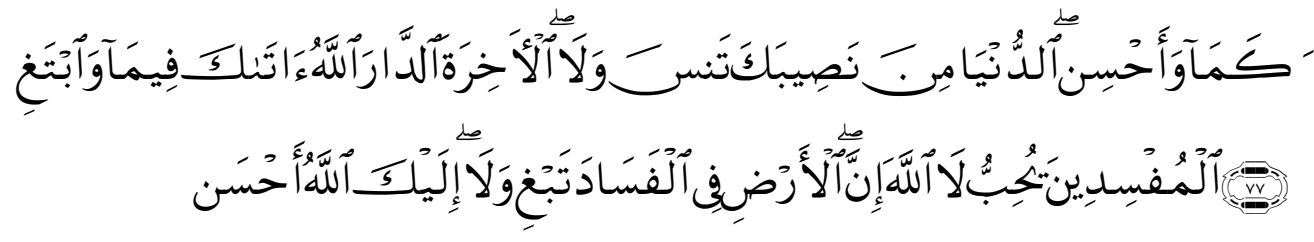


Artinya: dan carilah pada apa yang telah dianugerahkan Allah kepadamu (kebahagiaan) negeri akhirat, dan janganlah kamu melupakan bahagianmu dari (kenikmatan) duniawi dan berbuat baiklah (kepada orang lain) sebagaimana Allah telah berbuat baik, kepadamu, dan janganlah kamu berbuat kerusakan di (muka) bumi. Sesungguhnya Allah tidak menyukai orang-orang yang berbuat kerusakan.(Q.S.Al Qashash: 28/77)

Ayat ini menunjukkan kepada prinsip integritas di mana diri dan segala yang ada padanya dikembangkan pada satu arah, yakni kebajikan dalam rangka pengabdian kepada Tuhan.

Kedua, Prinsip Keseimbangan. Karena ada prinsip integrasi, prinsip keseimbangan merupakan kemestian, sehingga dalam pengembangan dan pembinaan manusia tidak ada kepincangan dan kesenjangan.Keseimbangan antara material dan spiritual, unsur jasmani dan rohani.Pada banyak ayat al-Qur'an Allah menyebutkan iman dan amal secara bersamaan.Tidak kurang dari enam puluh tujuh ayat yang menyebutkan iman dan amal secara besamaan, secara implisit menggambarkan kesatuan yang tidak terpisahkan. Diantaranya adalah



Artinya: demi masa; Sesungguhnya manusia itu benar-benar dalam kerugian; kecuali orang-orang yang beriman dan mengerjakan amal saleh dan nasehat menasehati supaya mentaati kebenaran dan nasehat menasehati supaya menetapi kesabaran. (Q.S. Al 'Ashr: 103/ 1-3)

Ketiga, Prinsip Persamaan. Prinsip ini berakar dari konsep dasar tentang manusia yang mempunyai kesatuan asal yang tidak membedakan derajat, baik antara jenis kelamin, kedudukan sosial, bangsa, maupun suku, ras, atau warna kulit. Sehingga budak sekalipun mendapatkan hak yang sama dalam pendidikan. Nabi Muhammad Saw bersabda

"Siapapun di antara seorang laki laki yang mempunyai seorang budak perempuan, lalu diajar dan didiknya dengan ilmu dan pendidikan yang baik kemudian dimerdekakannya lalu dikawininya, maka (laki laki) itu mendapat dua pahala" (HR. Bukhori). 
Keempat, Prinsip Pendidikan Seumur Hidup. Sesungguhnya prinsip ini bersumber dari pandangan mengenai kebutuhan dasar manusia dalam kaitan keterbatasan manusia di mana manusia dalam sepanjang hidupnya dihadapkan pada berbagai tantangan dan godaan yang dapat menjerumuskandirinya sendiri ke jurang kehinaan.Dalam hal ini dituntut kedewasaan manusia berupa kemampuan untuk mengakui dan menyesali kesalahan dan kejahatan yang dilakukan, disamping selalu memperbaiki kualitas dirinya. Sebagaimana firman Allah,

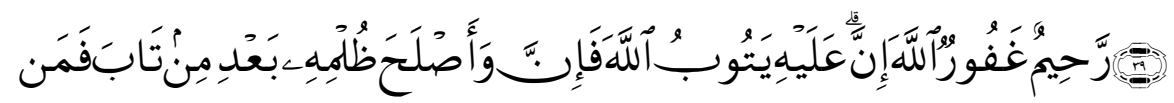

Artinya: Maka Barangsiapa bertaubat (di antara pencuri-pencuri itu) sesudah melakukan kejahatan itu dan memperbaiki diri, Maka Sesungguhnya Allah menerima taubatnya. Sesungguhnya Allah Maha Pengampun lagi Maha Penyayang. (Q.S. Al Maidah: 05/39).

Kelima, Prinsip Keutamaan. Dengan prinsip ini ditegaskan bahwa pendidikan bukanlah hanya proses mekanik melainkan merupakan proses yang mempunyai ruh dimana segala kegiatannya diwarnai dan ditujukan kepada keutamaan-keutamaan. Keutamaan-keutamaan tersebut terdiri dari nilai nilai moral.Nilai moral yang paling tinggi adalah tauhid.Sedangkan nilai moral yang paling buruk dan rendah adalah syirik.Dengan prinsip keutamaan ini, pendidik bukan hanya bertugas menyediakan kondisi belajar bagi subjek didik, tetapi lebih dari itu turut membentuk kepribadiannya dengan perlakuan dan keteladanan yang ditunjukkan oleh pendidik tersebut.Nabi Saw bersabda, "Hargailah anak anakmu dan baikkanlah budi pekerti mereka," (HR. Nasa'i).

\section{Konsep Dasar pendidikan islam.}

Konsep dasar pendidikan islam merupakan system dan cara hidup dalam segala bidang kehidupan manusia, sehingga dalam sejarah umat manusia dimuka bumi ini hampir tidak ada kelompok manusia yang tidak menggunakan pendidikan sebagai alat transfer kebudayaan dan juga sebagai alat untuk meningkatkan kualitas Sumber Daya Manusianya.

Maka, jika dipelajari ajaran-ajaran agama islam tentang pendidikan secara umum akan terlihat bahwa Nabi SWT, sesuai dengan Wahyu Allah, telah 
menetapkan garis-garis besarnya.Wahyu pertama,dan Wahyu kedua, yang diturunkan Allah kepada Nabi Muhammad SAW telah member isarat bahwa pendidikan islam terdiri dari empat belahan besar,yaitu:pendidikan keagamaan; pendidikan akal dan pengetahuan; pendidikan akhlak mulia; dan pendidikan kesehatan dan jasmani.

Didalam khazanah pemikiran pendidikan islam terutama karya-karya ilmiah berbahasa arab,terdapat berbagai istilah yang digunakan para ulama'dalam memberikan pengertian tentang "pendidikan islam" dan sekaligus untuk diterapkan dalam konteks yang berbeda-beda.

Menurut Zakiyah Deradjat, pendidikan islam didefinisikan dengan sesuatu usaha untuk membina dan mengasuh peserta didik agar senantiasa dapat memahami ajaran islam secara seluruh.Definisi lain menyebutkan bahwa pendidikan islam merupakna proses yang mengarahkan manusia pada kehdupan yang lebih baik dan mengangkat derajat kemanusiaanyasesuai dengan kemampuan fitrah dan kemampuan ajarnya(pengaruh dari luar). Sedangkan Yusuf Qardhawi, mengatakan pendidikan islam adalah pendidikan manusia seutuhnya, akal dan hatinya,rohani dan jasmaninya, akhlak dan keterampilannya.

Para pemikir muslim membagi sumber atau dasar nilai yang dijadikan acuhan dalam pendidikan islam menjadi tiga bagian yaitu : Al-Qur'an, Hadits, dan ijtihat(ijma ulama).Sebagaimana yang diterangkan dalam surat An-Nisa'ayat 59 yang berbunyi :

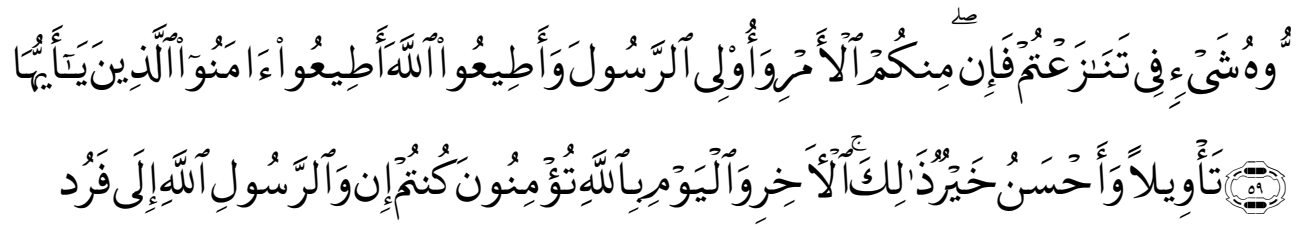

Artinya: Hai orang-orang yang beriman, taatilah Allah dan taatilah Rasul (Nya), dan ulil amri di antara kamu. kemudian jika kamu berlainan Pendapat tentang sesuatu, Maka kembalikanlah ia kepada Allah (Al Quran) dan Rasul (sunnahnya), jika kamu benar-benar beriman kepada Allah dan hari kemudian. yang demikian itu lebih utama (bagimu) dan lebih baik akibatnya. (Q.S. An-Nisa :04/59)

Dari sumber dasar tersebut dapat dideskripsikan sebagai berikut: 
Al-Qur'an, merupakan kalam Allah SWT yang memiliki perpendaharaan luas dan besar bagi pengembangan kebudayaan umat manusia.itu merupakan sumber pendidikan terlengkap baik itu pendidikankemasyarakatan(social),moral (akhlak), maupunspiritual(kerohanian), serta material (kejasmanian) dan alam semesta.

Hadits atau as-Sunnah, merupakan jalan atau cara yang pernah dicontohkan nabi dalam perjalanan kehidupannya melaksanakan dakwah islam. Contoh yang diberikan beliau dapat dibagi kepada tiga bagian yaitu: Hadits qauliyah, fi'liyah dan takririyah. Ini merupakan sumber dan acuan yang dapat digunakan umat islam dalam seluruh aktivitas kehidupannya. Hal ini disebabkan, meskipun secara umum bagian terbesar dari syariat islam telah terkandung dalam al-Qur'an namun muatan hukum tersebut belum mengatur berbagai dimensi aktifitas kehidupan umat secara terperinci dan analitis.

Dari sinilah dapat dilihat bagaimana posisi Hadist Nabi sebagai sumber atau dasar pendidikan islam yang utama setelah Al-Qur'an.Firman Allah SWT:

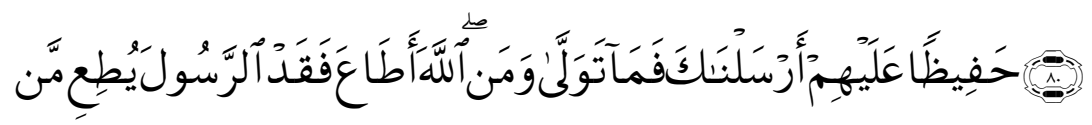

Artinya: Barangsiapa yang mentaati Rasul itu, Sesungguhnya ia telah mentaati Allah. dan Barangsiapa yang berpaling (dari ketaatan itu), Maka Kami tidak mengutusmu untuk menjadi pemelihara bagi mereka. (QS.An-Nisa' : 4/80)

Dari ayat di atas dapat dilihat dengan jelas bahwa kedudukan Hadist nabi merupakan dasar utama yang dapat dipergunakan sebagai acuan bagi pelaksanaan pendidikan islam yang dapat ditiru dan dijadikan referensi teoritis maupun praktis.

Dalam pendidikan, ikatan antara tanggung jawab dan proses pembelajaran serta hasil menjadi kesatuan utuh yang saling melengkapi. Mendidik adalah kegiatan memberi pengajaran, membuat seorang memahami, dan dengan pemahaman yang dimiliki peserta didik dapat mengembangkan potensi diri dengan menerapkan apa yang dipelajari. Proses itu dapat berlangsung seumur hidup dan pencapaian tujuan pendidikan tidak akan berhenti saat kehidupan seseorang berakhir. 
Dalam kurikulum terbaru yang dirilis pemerintah saat ini (KTSP Kurikulum Tingkat Satuan Pendidikan dan Kurikulum 2013), sekolah menjadi penyelenggara pendidikan yang berhak menentukan sendiri indikator-indikator bagi setiap kompetensi dasar dari semua mata pelajaran.Apakah hak itu digunakan untuk menentukan desain yang tepat dan selaras dengan tujuan pendidikan yang sebenarnya? Dalam minggu-minggu awal, peserta didik tingkat sekolah dasar akan dihadapkan dengan tiga tema sentral -mengenal diri, keluarga, dan lingkungan. Tentu saja tema-tema yang dipilih itu baik adanya untuk memperkenalkan kehidupan kepada anak, meskipun penggunaan kurikulum 2013 belum maksimal dilaksanakan dengan berbagai alas an tertentu.

Tapi akan lebih baik lagi jika sebelum tema-tema itu dipelajari, peserta didik dikenalkan kepada tema lain yang lebih mendasar dan mendalam -mengenal Sang Khalik. Dengan pengenalan akan Sang Pencipta, peserta didik akan memahami keberadaan dirinya di alam semesta ini dan dilatih untuk memuliakan Tuhan dalam kesehariannya.

Dengan mempelajari tema dasar ini, peserta didik akan dibawa ke satu ruangan belajar yang lebih besar daripada ruang kelas. Seluruh alam adalah ruang kelas. Karena keterangan dan kisah tentang penciptaan ada di kitab suci, maka kitab suci haruslah memiliki porsi terbanyak dan terutama.Tujuan pendidikan sejati tidaklah hanya mengisi ruang-ruang imajinasi dan intelektual anak, mengasah kepekaan sosialnya, ataupun memperkenalkan mereka pada aspek kecerdasan emosi tapi lebih kepada mempersiapkan mereka untuk melayani Tuhan dan sesama untuk pencapaian yang lebih besar bagi kekekalan.

\section{Spiritualisasi Subyek Didik (Pendidik Dan Peserta Didik)}

\section{Memuliakan Guru}

Yang terpenting adalah interaksi antara guru dan murid.Komponenkomponen lain dalam sistem pendidikan hanya pendukung interaksi itu.Menjadi lembaga pendidikan bermutu maka guru meningkatkan mutu guru adalah yang utama.Lembaga pendidikan hebat guru harus hebat.Pandangan islam; guru harus dipandang waratsatul anbiya' 
(pewaris nabi) atau duta Tuhan. Ditangan merekalah mutu pembelajaran dipertaruhkan.

\section{Menghargai Siswa}

Sekolah efektif adalah menghargai siswa.Siswa dipandang sebagai subjek dan sosok pribadi yang memiliki potensi, motivasi, cita-cita, perasaan, pengalaman dan kebutuhan-kebutuhan sebagai manusia seperti rasa aman, harga diri dan aktualisasi diri.Memanggilnya dengan rasa penuh sayang, memperlakukan dengan iklas seperti anak sendiri.Kepala sekolah maupun para guru harus memiliki kepedulian siswa akan kondisi dan poblem yang dihadapi siswa dalam sekolah maupun tidak. Sehingga hubungan gurumurid menjadi dekat, saling memahami, saling empati, menghargai.Kondisi ini membantu kesuksesan guru dalam mengajar dan membantu murid belajar.

3. Hubungan Spiritualitas dan profesionalitas

Guru yang bekerja (mengajar mendidik) untuk mencari nafkah dan kehormatan berbeda dengan mereka yang bekerja karena allah dan untuk mengharapkan karidaan allah, walaupun sama sama profesinya.Yang didasari iklas dan mengharapkan ridho nallah sehingga bersih dari sifat sifat yang tidak baik.Dan menjadi berkah setiap pengabdiannya.Jika karena panggilan keimanan kepada Allah dalam rangka mengharapkan ridhaAllah guru yang seperti ini memiliki kekuatan pendorong, daya tahan dan energi ganda dalam mengembangkan tugasnya dan menghadapai perubahan.

4. Spiritualitas Sebagai seorang pendidik

Sebagai kepala sekolah perlu membuat siasat agar guru dan seluruh komunitas sekolah termasuk siswa memiliki motivasi, daya tahan energi rohaniah yang kokoh sehingga akselerasi menuju sekolah unggul dapat 
dicapai. Dengan langkah-langkah: pemahaman, pelatihan, pembiasaan dan pembudayaan.

a. Pemahaman

Lebih menekankan pemahaman dan penghayatan dari pada sekedar tahu.Contoh siswa tahu syarat dan rukun wudhu sahnya shalat tapi juga paham makna masing-masing dengan menghayati, menikmati serta memaknai tindakannya itu sehingga tahu hikmanya pula.

b. Pelatihan

Mengamalkan nilai dan ajaran agama siswa dan guru harus dilatih sebelum menjadi kebiasaan dan kebutuhan.Contoh, agar bisa baca al-Qur'an dengan baik dan benar dan dengan penuh penghayatan baik bacaan dan isinya.Hal ini dilakukan pelajaran pertama mulai pukul 06.30-06.45.Juga dilatih yang seperti shalat duha, shalat zuhur dan asar, berkorban, manasik haji, bersedekah fakir miskin dan anak yatim, peduli sesama teman dan guru yang dapat musibah, solat malam dan lain sebagainya.

b. Pembiasaan

Perkatan, semua warga sekolah harus membiasakan perkataan yang baik. Itu sangat penting dalam islam yaitu quran qauwlanma'rufan (perkataan yang pantas), qawlan syadidan (perkataan yang berbobot) qawlan karimah (perkataan yang mulia) dsb.Kualitas perkataan menggambarkan kualitas kepribadian seseorang. Anak harus dibiasakan mengucapkan kata dan kalimat yang benar seperti salam,tasbih, istigfar, tahmid, tahlil dalam kehidupan sehari-hari.

c. Sikap dan perbuatan

Sikap dan perbuatan muncul adanya norma norma yang di biasakan. sehingga keberhasilan pengembangan sekolah tersebut seperti sikap kesungguhan. Harus ditanamkan kepada siswa dan di contohkan para guru dalam belajar, dalam penampilan dan dalam bentuk apa saja.

d. Penampilan 
Penampilan yang baik merupakan salah satu bentuk kepedulian terhadap lembaga. Tanpa kami menghargai lembaga ini, apa kami mau menghargainya?Karena itu guru harus rapi apa saja.Penampilan fisik sekolah juga perlu untuk salah satu media untuk pembangunan SDM. Yang berupa mental suatu komunitas merupakan waktu yang lama, prinsipnya; mulai dari diri sendiri dari sekarang dari yang kecil-keci;1 perlu di terapkan. Sehingga tidak ada penunda nunda pekerjaan sampai nanti apabila dapat dituntaskan, sehingga sadar untuk mencapai yang besar harus dari yang kecil.

e. Penciptaan Kultur dan Iklim Pembelajaran yang Kondusif

Harus menyenangkan, mencerdaskan dan mengasikkan.Menyenangkan maksudnya harus mampu membangkitkan motivasi siswa.Untuk itu pendidik harus aktif dan kreatif, mencari trobosan-trobosan untuk meningkatkan kompetensi dan personalisasi sehingga guru menjadi profesional dalam mengajar berpribadian, dan dapat memberikan inspirasi bagi siswa.Mencerdaskan; pembelajaran mampu mengembangkan suasana keberanian, keterbukaan dan persamaan sehingga menumbuhkan imajinasi, cita-cita dan kreativitas.Akhirnya pembelajaran harus mengaksikan, siswa merasakan asyiknya melakukan kerja keilmuan seperti di laboratorium, perpustakaan, kebun percobaan, bengkel atau berdiskusi dengan sesama teman dan guru.

\section{E. Spiritualisasi Kepemimpinan Pendidikan Islam}

Dalam rangka melakukan pembaruhan pendidikan islam menjadi sekolah yang baik lagi benar (good school) bukan sekedar membutuhkan berbagai teori modernisasi dan pemberdayaan, melainkan jihad ; yaitu kerja keras lahir dan batin, penuh kesungguhan, keikhlasan, pengorbanan, kepahlawanan, keteladanan dan kepedulian dengan memobilisasi segala sumber daya untuk mencapai suatu cita-cita bersama, suci dan luhur. Jihad dengan demikian merupakan kata kunci 
(key word) untuk merubah kondisi pendidikan islam dari tidak diminati menjadi berprestasi, dari tidak berkualitas menjadi berkualitas, dari tidak berdaya menjadi berdaya. Beratnya perjuangan untuk melakukan perubahan terhadap pendidikan islam disebabkan kondisi pendidikan islam yang sebagian besar menghadapi siklus negative atau terbelenggu oleh lingkaran setan ketidakberdayaan.

Persoalannya adalah model kepemimpinan yang bagaimana yang cocok dan mampu merubah pendidikan islam yang sebagian besar terbelenggu dalam lingkaran ketidakberdayaan (siklus negative) menjadi lingkaran keberdayaan (siklus positif)? Kepemimpinan yang mampu mengembangkan ruh al-jihad? Kepemimpinan yang mampu mengembangkan pendidikan islam menjadi pendidikan yang efektif? Model kepemimpinan yang dimaksud tentu bukan model kepemimpinan yang biasa, melainkan kepemimpinan yang luar biasa.

\section{Konsep Spiritual Leadership}

Manusia terdiri dari unsur material dan spiritual atau unsur jasmani dan rohani, prilaku manusia merupakan produk tarik-menarik antara energy spiritual dan material atau antara dimensi ruhaniah dan jasmaniah. Dorongan spiritual senantiasa membuat kemungkinan membawa dimensi material manusia kepada dimensi spiritualnya (ruh, keilahian).Caranya adalah dengan memahami dan menginternalisasikan sifat-sifatnya, tujuanya adalah memperoleh ridha-Nya, menjadi "sahabat" Allah, "kekasih" Allah. Inilah manusia yang suci, yang keberadaanya membawa kegembiraan bagi manusia-manusia lainya

kepemimpinan spiritual adalah kepemimpinan yang membawa dimensi keduniawian kepada dimensi spiritual (keilahian). Tuhan adalah pemimpin sejati yang mengilhami, mempengaruhi, melayani, dan menggerakan hati nurani hambanya dengan cara yang sangat bijaksana melalui pendekatan etis dan keteladanan.

Dalam perspektif sejarah islam, spiritualitas telah terbukti menjadi kekuatan yang luar biasa untuk menciptakan individu-individu yang suci, memiliki integritas dan akhlakul karimah yang keberadaanya bermanfaat (membawa kegembiraan ) kepada yang lain. Secara social, kekuatan spiritualitas mampu membangun masyarakat islam mencapai puncak pradaban, mampu 
memcapai predikat khaira ummat dan keberadaanya membawa kebahagiaan untuk semua (rahmatan lil'alamin).

Kepemimpinan spiritual juga tidak berarti kepemimpinan dengan kekuata gaib sebagaimana terkandung dalam istilah "tokoh spiritual" atau "penasehat spiritual", melainkan kepemimpinan dengan menggunakan kecerdasan spiritual, lembaga penajaman mata batin atau indra keenam

\section{Spiritual leadership diantara model kepemimpinan lainya}

Sumber tindakan kepemimpinan yaitu kepemimpinan konvensional dan kepemimpinan spiritual yang dimaksud kepemimpinan konvesional adalah kepemimpinan yang lazim diterapkan dalam berbagai lembaga formal dan sebagaimana dikemukakan dalam literature-literatur ilmiah selama ini.Kepemimpinan konvesional menggunakan paradigma positivistic atau paradigma ilmiah dalam perilaku kepemimpinanya. Blanchard dalam hal ini mengatakan kalau kepemimpinan sejati adalah kepemimpinan yang muncul dari dalam diri keluar untuk melayani mereka yang dipimpinya (leaderdan ship from inside out)kepemimpinan konvesional sebaliknya.muncul dari luar ke dalam(leadership from outside in)lewat penghormatan dan pujian (honor and praise).kepemimpinan spiritual merupakan model kepemimpinan komprehensip yang menggabungkan berbagai pendekatan dan sekaligus kekuatan penggerakan kepemimpinan seperti kekuatan intelektual, moral,emosional dan spiritual .kepemimpinan spiritual merupakan gabungan dari model kepemimpinan etik,

\section{Karakteristik kepemimpinan spritual}

Sebagaimana dikemukakan di atas,kepemimpinan spiritual adalah kepemimpinan yang berbasis pada etika religious,kepemimpinan atas nama tuhan,yaitu kepemimpinan yang terilhami oleh perilaku etis tuhan dalam memimpin mahluk-mahluknya. Dalam panggung sejarah,rasul tuhan adalah contoh terbaik bagaimana kepemimpinan spiritual ditegakkan.oleh rasul tuhan itu terilham dan untuk selanjutnya mereka terapkan dalam memimpin sesama manusia. 
Berikut dikemukakan pokok-pokok karakteristik kepemimpinan spiritual yang berbasis pada etika religious yang dirujuk dari berbagai sumber di atas, yaitu: kejujuran sejati,pengenalan diri sendiri,focus pada amal saleh,spiritualisme yang tidak dogmatis,bekerja lebih efisien,membangkitkan yang terbaik dalam diri sendiri dan orang lain,keterbukaan menerima perubahan,think globally act locally,disiplin tetapi tetap fleksibel,santai dan cerdas,dan kerendahan hati.

\section{F. Integrasi Ilmu Pengetahuan (Spiritualisasi Kurikulum)}

Merupakan sesuatu yang diidamkan para pemikir dan cendikiawan Muslim.Cara membangunnya yang efektif adalah melalui pendidikan. Contoh lembaga pendidikan islam yang telah mencoba dengan dilihat dari;Body of knowledge dari kurikulum yang di kembangkan baik formal curriculum maupunhidden curriculum-nya.

Hal ini dimulai dari syahadat kemudian diakhiri dengan mengharapkan ridho Allah, termasuk pengembangan ilmu.Karena Allah menciptakan dan mengajarkan ilmu pengetahuan Zat maha mengetahui lewat ayat-ayat Nya. Ilmu agama dan umum semuanya sama karena sumbernya dari yang tunggal yaitu Allah SWT, dan bermuara pada tujuan yang sama ridhaAllah.Perbedaanperbedaan dalam kehidupan ini seperti siang malam jasmani rohani dll. Antara agama dan ilmu harus berpasangan untuk menciptakan kekuatan berilmu pengetahuan akan membantu orang menjadi saleh yaitu digambarkan dalam tujuan pendidikan sebagai orang yang memiliki kedalaman spiritual, keagungan akhlak, keluasan ilmu dan kematangan profesional.

\section{G. Penutup.}

Untuk mewujudkan Spritulitas Pendidikan Islam harus fokus dominan terjadinya perubahan dari sekolah tidak diminati menjadi berprestasi.Mengembangkan pendidikan Islam dan peran yang dilakukan dalam mengembangkannya:

a. Sebagai Pembaharu, gagasan-gagasan atau ide-ide baru senantiasa keluar dari hasil kontemplasi, penjelajahan dan pengembangan Intelektualnya yang luas. 
b. Pemimpin Spiritual sebagai Pemimpin Organisasi Pendidikan. Pemimpin mampu merendahkan diri sehingga mampu mengefektifkan budaya dan proses organisasi dan mengembangkan usaha dan laba. Berperan sebagai tokoh pergerakan, ruhaniawan, relawan dan volunteer yang pandai menarik simpati dan menggerakan massa tokoh spiritual dan seorang pekerja social

c. Pemimpin Spritual sebagai Administrator Proses Pembelajaran. Sebagai tugas yang telah ada pembagian tugas dan sekaligus sebagai bentuk pengkaderan. Hal ini berperan sebagai pengilham, pencerah dan pembangkit.

d. Pemimpin Spritual Sebagai Pendidik. Yaitu mampu mengefektifkan proses pembelajaran danmelakukan berbagai inovasi. Mampu mengembangkan pemikiran dan ide-ide baru,mencerahkan dan memberdayakan sehingga pendidikan benar-benar memerankan fungsi pokoknya, bukan sekedar fungsi formalnya. Melakukan inovasi proses pembelajaran:(1) Mengarah pada pembentukan kesalehan yaitu dalam prilaku, berilmu;(2) Spritualisasi kurikulum; (3) Spritualisasi proses pembelajaran; (4) Spritualisasi subyek didik.Spritualitas asketik yaitu intensitas pengabdian kepada tuhan yang dijalankan dalam kegairahan kerja yang dapat membuahkan kesalehan.

\section{DAFTAR PUSTAKA}

An-Nahlawi, Abdurrahman,Pendidikan Islam di Rumah, Sekolah, dan Masyarakat,Jakarta: Gema Insani Press, 1995

Jalaluddin dan Usman Said, Filsafat Pendidikan Islam, Jakarta: Raja Grafindo Persada, 1996)

Langgulung, Hasan, Asas-asas Pendidikan Islam, Jakarta: Pustaka al-Husna, 1992 
Sidi, Indra Djati, Menuju masyarakat Belajar: Menggagas Paradigma Baru Pendidikan, Jakarta: Paramadina, 2001

Saelan, Maulawi, Spritualisasi Pendidikan, Pendidikan Alternatif Abad 21, Jakarta: Yayasan Syifa Budi, 2002

Ramayulis, Ilmu Pendidkan Islam, Jakarta:Kalam Mulia, 1994

Tobroni, Pendidikan Islam; Paradigma Teologis, Filosofis dan Spritualitas, Malang: UMM Press, 2008

Wirjosukarto, Pembaharuan Pendidikan dan Pengajaran Islam, Yogyakarta:1962

Zohar, Danah, Memanfaatkan Kecerdasan Spritual dalam Berpikir Integralistik dan Holistik untuk Memaknai Kehidupan, Bandung: Mizan, 2001

http://adji-anginkilat.blogspot.com/2011/05/prinsip-prinsip-pendidikan-agama

islam.html

http://jawaposting.blogspot.com/2011/06/c-integrasi-knowledge-

spiritualisasi.html

http://id.shvoong.com/social-sciences/education/1787120-tujuan-dan-sumberpendidikan/\#ixzz279dXNREZ 